\title{
EVALUASI SEKOLAH SATU ATAP TERPADU DENGAN MENGGUNAKAN ANALISIS SWOT-ANALYTIC NETWORK PROCESS (STUDI KASUS DI KABUPATEN PURWAKARTA)
}

\author{
Abi Revyansah Perwira ${ }^{1}$ \\ Bayu Kharisma ${ }^{2}$
}

Fakultas Ekonomi dan Bisnis Universitas Padjadjaran, Jawa Barat, Indonesia ${ }^{1,2}$ JL. Dipati Ukur No. 35 Bandung, 40132, Indonesia. Email: abi.revyansah@bps.go.id

\begin{abstract}
Integrated One-Stop School Evaluation Using Analysis SWOT-Analytic Network Process (Case Study in Purwakarta Regency). One way to reduce dropout rates is through a Sekolah Satu Atap Terpadu. One of the regencies in West Java that has organized a Sekolah Satu Atap Terpadu as well as the object of this research is Purwakarta regency. By using SWOTAnalytic Network Process (ANP) analysis, this study seeks to evaluate while providing alternative policies for the development of Sekolah Satu Atap Terpadu in Purwakarta regency. The data in this study were obtained by filling out questionnaires by respondents online through Google Form, where respondents were actors who were directly involved in the implementation of a Sekolah Satu Atap Terpadu. From the analysis results obtained Strengths and Threats occupy the highest value. Strengths include students could continue their education up to junior high school level and local government supports both in terms of budget and curriculum. While Threats, among others, school management has become more complex and the delegation of authority from the central and regional governments is not clear. Therefore, the ST strategy can be used as an alternative policy in increasing Strengths and minimizing Threats.
\end{abstract}

Keywords: Sekolah Satu Atap Terpadu; SWOT Analysis; Analytic Network Process (ANP).

Abstrak: Evaluasi Sekolah Satu Atap Terpadu Dengan Menggunakan Analisis SWOTAnalytic Network Process (Studi Kasus di Kabupaten Purwakarta). Salah satu cara untuk mengurangi angka putus sekolah adalah melalui Sekolah Satu Atap Terpadu. Salah satu kabupaten di Jawa Barat yang telah menyelenggarakan Sekolah Satu Atap Terpadu sekaligus sebagai obyek penelitian ini adalah kabupaten Purwakarta. Dengan menggunakan analisis SWOT-Analytic Network Process (ANP), penelitian ini berusaha mengevaluasi sekaligus memberikan alternatif kebijakan untuk pengembangan Sekolah Satu Atap Terpadu di kabupaten Purwakarta. Data dalam penelitian ini diperoleh dengan cara pengisian kuesioner oleh para responden secara online melalui Google Form, dimana responden adalah aktor-aktor yang terlibat langsung dalam penyelenggaraan Sekolah Satu Atap Terpadu. Dari hasil analisis diperoleh Strengths dan Threats menduduki nilai yang paling tinggi. Strengths antara lain siswa bisa melanjutkan pendidikan sampai tingkat SMP dan dukungan pemerintah daerah baik dari sisi anggaran maupun kurikulum. Sedangkan Threats antara lain manajemen sekolah menjadi lebih kompleks dan pelimpahan wewenang baik dari pemerintah pusat maupun daerah yang tidak jelas. Oleh karena itu, strategi ST bisa dijadikan alternatif kebijakan dalam meningkatkan Strengths dan meminimalisir Threats.

Kata Kunci: Sekolah Satu Atap Terpadu; Analisis SWOT; Analytic Network Process (ANP). 


\section{PENDAHULUAN}

Pada era modern seperti sekarang ini, pendidikan sudah merupakan kewajiban bagi penduduk suatu negara untuk memperolehnya baik formal maupun informal. Dengan pendidikan, seseorang bisa memperbaiki taraf hidup dirinya sendiri maupun keluarganya dalam lingkup kecil. Jika dilihat dari aspek yang luas, pendidikan merupakan investasi sumber daya manusia untuk pembangunan suatu negara di masa depan. Jadi kualitas sumber daya manusia masa yang akan datang dipengaruhi oleh kualitas pendidikan saat ini. Oleh karena itu, demi terwujudnya sumber daya masyarakat yang berkualitas, peran orang tua, pemerintah, masyarakat sangat penting.

Pemerintah Indonesia sadar akan pentingnya pendidikan bagi warga negaranya dan berusaha untuk melaksanakan pemerataan pendidikan di seluruh wilayah Indonesia. Sesuai dengan Undang-undang nomor 20 tahun 2003, pemerintah menjamin bahwa setiap warga negara Indonesia berhak memperoleh pendidikan yang bermutu dan mengalokasikan dana pendidikan sebesar $20 \%$ baik dari APBN maupun APBD.

Meskipun pemerintah sudah mencanangkan program wajib belajar 9 tahun bagi seluruh warga negara Indonesia dan menganggarkan 20\% dari anggaran untuk pendidikan, masih ada permasalahan pendidikan yang belum terselesaikan di negeri ini. Kurang meratanya akses pendidikan, tingginya angka putus sekolah, dan rendahnya kualitas pendidikan masih menjadi gambaran umum kondisi pendidikan di Indonesia, terutama daerah-daerah dengan kondisi geografis yang sulit. Sehingga perlu strategi yang tepat dalam menangani masalah-masalah yang timbul dalam dunia pendidikan di Indonesia.

Diprovinsi Jawa Baratsendirijumlah siswa tingkat SMP jauh lebih sedikit dibandingkan jumlah siswa tingkat SD, hanya sekitar 39\% (Tabel 1). Fakta ini sangat mengejutkan, karena sebanyak lebih dari $60 \%$ peserta didik tingkat
SD tidak bisa melanjutkan ke tingkat SMP. Data ini menunjukkan bahwa program wajib belajar 9 tahun bisa dikatakan kurang sukses di salah satu provinsi berpenduduk paling padat seIndonesia. Untuk mengatisipasi hal ini, program Sekolah Satu Atap Terpadu bisa dijadikan sebagai salah satu alternatif strategi.

Program Sekolah Satu Atap Terpadu adalah sekolah dimana SD dan SMP berada pada satu lokasi yang sama dengan tujuan siswa SD yang telah lulus bisa melanjutkan ke jenjang SMP di lokasi yang sama (Sugiharto, 2013). Program ini memperbesar peluang anak-anak usia sekolah untuk bisa mengenyam pendidikan dasar 9 tahun dan mengurangi angka putus sekolah.

Kementerian Pendidikan dan Kebudayaan secara bertahap telah mengembangkan Sekolah Satu Atap Terpadu terutama bagi anakanak yang berada di daerah dengan kondisi infrastruktur yang minim dan geografis yang sulit sehingga kebutuhan pendidikan dasar mereka terakomodir (Mahmud, 2015).

Salah satu kabupaten di Jawa Barat yang telah melaksanakan program Sekolah Satu Atap Terpadu sekaligus menjadi fokus utama penelitian ini adalah kabupaten Purwakarta. Selain telah melaksanakan program Sekolah Satu Atap Terpadu, pemerintah kabupaten Purwakarta juga telah menerapkan kebijakan lokal di bidang pendidikan seperti kurikulum program Baca Tulis Qur'an (BTQ) dan pendidikan karakter berbasis kearifan lokal (Gunawan, et al., 2017). Akan tetapi, dalam pelaksanaan program Sekolah Satu Atap Terpadu masih ditemui tantangan dan hambatan.

Berdasarkan latar belakang di atas, penelitian ini berusaha untuk menganalisa faktor eksternal dan internal yang mempengaruhi pelaksanaan program Sekolah Satu Atap Terpadu dengan metode analisis SWOTAnalytic Network Process (ANP). Hasil analisis penelitian ini diharapkan mampu memberikan kontribusi yang nyata sekaligus sebagai bahan evaluasi terhadap pelaksanaan program Sekolah 
Tabel 1.

Jumlah Siswa SD dan SMP di Jawa Barat tahun 2017 - 2019

\begin{tabular}{|c|c|c|c|c|c|c|}
\hline \multirow{2}{*}{ Wilayah } & \multicolumn{2}{|c|}{2017} & \multicolumn{2}{|c|}{2018} & \multicolumn{2}{|c|}{2019} \\
\hline & SD & SMP & SD & SMP & SD & SMP \\
\hline Kab. Bogor & 511,350 & 203,075 & 514,452 & 203,589 & 519,265 & 202,522 \\
\hline Kab. Garut & 370,432 & 138,792 & 367,545 & 138,380 & 364,598 & 134,924 \\
\hline Kab. Bandung & 305,096 & 115,438 & 307,632 & 116,364 & 304,997 & 115,403 \\
\hline Kab. Cianjur & 286,284 & 104,210 & 281,841 & 104,483 & 276,913 & 103,274 \\
\hline Kab. Sukabumi & 231,945 & 110,451 & 228,494 & 107,544 & 224,656 & 102,684 \\
\hline Kab. Tasikmalaya & 255,253 & 95,137 & 254,867 & 94,785 & 250,069 & 93,975 \\
\hline Kab. Bekasi & 244,242 & 97,124 & 240,862 & 96,186 & 240,160 & 95,244 \\
\hline Kota Bandung & 226,305 & 88,379 & 224,651 & 86,086 & 224,730 & 84,600 \\
\hline Kab. Indramayu & 234,951 & 88,783 & 231,828 & 88,245 & 230,235 & 86,475 \\
\hline Kab. Cirebon & 201,772 & 78,070 & 199,996 & 77,871 & 199,284 & 78,394 \\
\hline Kota Bekasi & 167,729 & 64,888 & 167,979 & 64,983 & 166,655 & 63,471 \\
\hline Kab. Karawang & 159,504 & 62,824 & 157,238 & 61,351 & 160,442 & 63,484 \\
\hline Kab. Subang & 163,851 & 64,406 & 161,216 & 64,676 & 158,702 & 59,981 \\
\hline Kab. Bandung Barat & 157,915 & 61,609 & 157,243 & 62,194 & 156,852 & 61,396 \\
\hline Kab. Ciamis & 142,709 & 62,052 & 141,156 & 60,639 & 139,705 & 59,236 \\
\hline Kota Depok & 106,901 & 45,667 & 107,217 & 45,066 & 105,644 & 43,813 \\
\hline Kab. Majalengka & 113,524 & 39,002 & 112,114 & 38,120 & 112,004 & 38,102 \\
\hline Kab. Kuningan & 104,110 & 44,868 & 103,581 & 44,582 & 103,326 & 43,534 \\
\hline Kab. Sumedang & 103,219 & 41,070 & 102,274 & 40,994 & 102,141 & 40,042 \\
\hline Kab. Purwakarta & 99,497 & 39,467 & 98,641 & 39,797 & 98,529 & 39,667 \\
\hline Kota Bogor & 95,318 & 39,501 & 93,889 & 39,048 & 93,145 & 37,685 \\
\hline Kota Tasikmalaya & 64,560 & 28,954 & 64,210 & 28,484 & 64,334 & 28,108 \\
\hline Kab. Pangandaran & 51,501 & 22,358 & 51,612 & 21,369 & 51,596 & 20,613 \\
\hline Kota Cirebon & 36,463 & 19,886 & 36,101 & 19,373 & 35,434 & 18,730 \\
\hline Kota Sukabumi & 33,040 & 16,241 & 33,015 & 16,372 & 32,807 & 16,103 \\
\hline Kota Cimahi & 33,193 & 13,204 & 32,724 & 13,064 & 32,660 & 13,160 \\
\hline Kota Banjar & 15,806 & 7,862 & 15,815 & 7,821 & 15,798 & 7,868 \\
\hline Total & $4,516,470$ & $1,793,318$ & $4,488,193$ & $1,781,466$ & $4,464,681$ & $1,752,488$ \\
\hline
\end{tabular}

Sumber: Direktorat Jenderal Pendidikan Dasar dan Menengah (2019)

Satu Atap Terpadu. Gambaran umum masyarakat di Purwakarta. Fokus lokasi penelitian ini adalah kabupaten Purwakarta yang dilaksanakan pada tanggal 24 April - 30 Juni 2019. Kabupaten Purwakarta berdiri tahun 1968 berdasarkan Undang-undang nomor 4 tahun 1968. Kabupaten Purwakarta terletak antara $107^{\circ} 30^{\prime}-107^{\circ} 40^{\prime}$ Bujur Timur dan $6^{\circ} 25^{\prime}-6^{\circ} 45^{\prime}$ Lintang Selatan berbatasan dengan kabupaten Karawang dan kabupaten Subang di sebelah Utara, kabupaten
Bandung Barat dan Cianjur di sebelah selatan, kabupaten Karawang, Cianjur, dan Bogor di sebelah barat, serta kabupaten Subang dan Bandung Barat di sebelah Timur. Kabupaten Purwakarta mempunyai 17 kecamatan, 183 desa, 9 kelurahan, 505 dusun, 1,125 Rukun Warga (RW), dan 3,498 Rukun Tetangga (RT) dengan luas wilayah sebesar $971.72 \mathrm{~km}^{2}$ (Pemerintah Kabupaten Purwakarta, 2019).

Kabupaten Purwakarta pada tahun 2017 
mempunyai Indeks Pembangunan Manusia (IPM) sebesar 69.82 dan total Produk Domestik Regional Bruto (PDRB) sebesar 58,522.23 juta rupiah. Jumlah penduduk pada tahun 2017 sebanyak 943,447 jiwa dengan rincian 479,713 berjenis kelamin laki-laki dan 463,624 berjenis kelamin wanita. Rata-rata jumlah penduduk per rumah tangga adalah 4 orang dan kepadatan penduduk 970 jiwa $/ \mathrm{km}^{2}$ pada tahun yang sama (Badan Pusat Statistik Kabupaten Purwakarta, 2018).

Kabupaten Purwakarta mempunyai total 749 sekolah terdiri dari 468 sekolah SD terdiri dari 381 SD negeri dan 87 SD swasta, 165 sekolah SMP terdiri dari 83 SMP negeri dan 82 SMP swasta, 58 Sekolah SMU terdiri dari 18 SMU negeri dan 40 SMU swasta, dan 58 Sekolah SMK terdiri dari 15 SMK negeri dan 43 SMK swasta (Kementerian Pendidikan \& Kebudayaan, 2019).

\section{METODE PENELITIAN}

Metode yang digunakan dalam penelitian ini adalah analisis SWOT-Analytic Network Process (ANP). Analisis SWOT merupakan alat yang sering digunakan dalam membuat suatu keputusan atau kebijakan. Analisis ini mengidentifikasi faktor internal yang terdiri dari Strengths (Kekuatan) dan Weaknesses (Kelemahan) dan faktor eksternal yang terdiri dari Opportunities (Peluang) dan Threats (Ancaman). Berdasarkan hasil identifikasi bisa diperoleh keputusan/kebijakan strategis yang bisa meningkatkan Strengths, mengurangi Weaknesses, memanfaatkan Opportunities, dan mencegah Threats. Dari hasil analisis SWOT bisa disusun matriks strategi keputusan/ kebijakan seperti pada Tabel 2.

Dari Tabel 2 terlihat bahwa ada empat strategi alternatif yang bisa digunakan. Berdasarkan Yüksel \& Dağdeviren (2007), strategi SO adalah strategi yang memanfaatkan Opportunities dengan menggunakan Strengths yang ada. Strategi WO berupaya untuk mendapatkan manfaat dari Opportunities yang disajikan oleh faktor eksternal dengan memperhitungkan Weaknesses. Demikian pula, ST adalah strategi yang terkait dengan menggunakan Strengths untuk menghilangkan atau mengurangi efek Threats. Strategi keempat dan terakhir adalah WT, dimana organisasi mencoba untuk mengurangi efek Threats dengan memperhitungkan Weaknesses. Dalam penelitian ini, tujuan analisis SWOT adalah untuk menentukan prioritas strategi yang dikembangkan dan untuk menentukan strategi terbaik.

Namun, hasil analisis SWOT sering hanya daftar atau pemeriksaan kualitatif yang tidak lengkap dari faktor internal dan eksternal. Karena alasan ini, analisis SWOT tidak dapat menilai secara komprehensif proses pengambilan keputusan/kebijakan strategis (Yüksel \& Dağdeviren, 2007).

Oleh karena itu, metode Analytic Network Process (ANP) digunakan dalam penelitian ini untuk menilai hasil identifikasi dari analisis SWOT. Tanjung \& Devi (2013) dalam Kharisma \& Hadiyanto (2018) menyebutkan bahwa metode ini merupakan pengembangan dari metode kualitatif sebelumnya yaitu Analytical Hierarchy Process (AHP). Banyak permasalahan terjadi tidak terstruktur secara hierarki karena melibatkan ketergantungan

Tabel 2.

Matriks SWOT

\begin{tabular}{ccc}
\hline \multirow{2}{*}{ Faktor Eksternal } & \multicolumn{2}{c}{ Faktor Internal } \\
\cline { 2 - 3 } Opportunities (O) & Strengths $(\mathbf{S})$ & Weaknesses $(\mathbf{W})$ \\
\hline Threats $(\mathbf{T})$ & Strategi SO & Strategi WO \\
\hline
\end{tabular}


elemen antar tingkat hierarki itu sendiri. Permasalahan seperti ini tidak bisa diselesaikan dengan metode AHP karena metode ini bersifat satu arah secara hierarki, namun metode ANP memiliki kemampuan untuk mengakomodasi hubungan timbal-balik yang kompleks antar tingkat hierarki (Görener, 2012).

Metode ANP merupakan penggabungan dari 2 bagian, bagian pertama terdiri dari hierarki kontrol atau jaringan kriteria dan subkriteria yang mengontrol interaksi dan bagian kedua adalah jaringan pengaruh antara unsur-unsur dan kelompok (Saaty, 1999). Jaringan ini bervariasi antara satu kriteria dengan kriteria yang lain dan supermatriks yang membatasi pengaruh dibentuk untuk setiap kriteria kontrol. Masing-masing supermatriks ini ditimbang dengan prioritas kriteria kontrolnya dan hasil penimbangan ini disintesis melalui penambahan untuk semua kriteria kontrol. Keterkaitan antara kriteria pada metode ANP memiliki dua jenis; hubungan dalam satu set elemen (ketergantungan dalam) dan keterkaitan antara elemen yang berbeda (ketergantungan luar) (Kharisma \& Hadiyanto, 2018).

Görener (2012) membagi pengambilan keputusan dengan ANP melalui beberapa tahapan sebagai berikut: (1) Pembentukan model keterkaitan dan struktur permasalahan dimana suatu permasalahan harus dinyatakan dengan jelas dan didekomposisi menjadi sistem rasional seperti jaringan; (2) Pembentukan matriks perbandingan dan prioritas berpasangan dimana pasangan-pasangan elemen keputusan di setiap cluster dibandingkan dengan skala prioritasnya terhadap kriteria kontrol; (3) Pembentukan matriks super yang sebenarnya merupakan matriks yang terpartisi dimana setiap segmen segmen matriks adalah representasi hubungan antara dua kelompok dalam suatu sistem; (4) Sintesis kriteria dan prioritas alternatif dan pemilihan alternatif terbaik dimana bobot prioritas kriteria dan alternatif dapat ditemukan dalam matriks super yang dinormalisasi.

\section{PEMBAHASAN}

Penggunaan SWOT-Analytic Network Process (ANP) dalam penelitian ini bisa memberikan hasil yang bisa dijadikan acuan dalam perumusan kebijakan pengembangan Sekolah Satu Atap Terpadu, namun terdapat kendala-kendala seperti berikut (Saaty, 2008). (1) Adanya variabel sulit untuk diukur atau tidak dapat diukur, seperti perilaku aktor-aktor yang terlibat, kondisi sosial dan budaya yang berlaku di wilayah yang diteliti; (2) Adanya nilai-nilai variabel yang bersifat subyektif dari penilaian konsensus; (3) Adanya keterbatasanketerbatasan dalam memperoleh baik data sekunder maupun primer seperti akses dan ketersediaan data; (4) Adanya keterkaitan yang kompleks dari faktor-faktor yang diteliti sehingga membutuhkan pemahaman komprehensif dan holistik untuk menghindari kesalahan analitis dalam mengambil kesimpulan atau keputusan.

Metode pemilihan responden dilakukan dengan cara purposive sampling berdasarkan pengetahuan ataujudgment sampling. Metode ini dipilih karena mempertimbangkan pemahaman responden tentang masalah Sekolah Satu Atap Terpadu. Responden yang dipilih dalam hal ini adalah orang yang memiliki pengetahuan, kompetensi, dan/atau pengalaman yang cukup terkait dengan kegiatan Sekolah Satu Atap Terpadu di kabupaten Purwakarta seperti kepala sekolah, guru, dan pegawai sekolah non guru. Melalui kuesioner yang dibuat dengan menggunakan aplikasi Google Form dan dibagikan secara online, diperoleh 5 responden yang merupakan aktor langsung yang terlibat dalam kegiatan Sekolah Satu Atap Terpadu.

Dari hasil penelitian-penelitian sebelumnya dan wawancara dengan pihak terkait diperoleh hasil analisis SWOT seperti dalam Tabel 3.

Analisis SWOT-ANP pada Gambar 1 menunjukkan bahwa faktor yang mendominasi Sekolah Satu Atap Terpadu di kabupaten Purwakarta adalah Strengths, yang mencapai 
Tabel 3.

Analisis SWOT Sekolah Satu Atap Terpadu di Kabupaten Purwakarta

\begin{tabular}{|c|c|c|}
\hline No & Indikator & Penjelasan \\
\hline \multicolumn{3}{|r|}{ Strengths (Kekuatan) } \\
\hline 1 & Lokasi Sekolah & $\begin{array}{l}\text { Sekolah Satu Atap Terpadu dibangun tidak jauh dari } \\
\text { tempat tinggal siswa terutama siswa di daerah terpencil }\end{array}$ \\
\hline 2 & $\begin{array}{l}\text { Kelanjutan Pendidikan ke } \\
\text { Tingkat SMP }\end{array}$ & $\begin{array}{l}\text { Siswa yang telah lulus SD mempunyai peluang yang lebih } \\
\text { besar untuk melanjutkan ke tingkat SMP }\end{array}$ \\
\hline 3 & $\begin{array}{l}\text { Kurikulum Berbasis } \\
\text { Kearifan Lokal }\end{array}$ & $\begin{array}{l}\text { Kurikulum pendidikan berbasis kearifan lokal merupakan } \\
\text { cara khusus untuk meningkatkan kualitas pendidikan } \\
\text { sekaligus melestarikan budaya lokal }\end{array}$ \\
\hline 4 & $\begin{array}{l}\text { Dukungan Pemerintah } \\
\text { Daerah }\end{array}$ & $\begin{array}{l}\text { Kepedulian pemerintah daerah tinggi baik secara materiil } \\
\text { maupun non materiil }\end{array}$ \\
\hline \multicolumn{3}{|r|}{ Weaknesses (Kelemahan) } \\
\hline 1 & Guru Profesional & $\begin{array}{l}\text { Jumlah guru profesional yang mengajar masih kurang } \\
\text { baik dari segi kompetensi maupun kualitas }\end{array}$ \\
\hline 2 & Ruang Kelas & $\begin{array}{l}\text { Jumlah ruang kelas yang tersedia untuk kegiatan belajar- } \\
\text { mengajar belum sesuai dengan jumlah siswa }\end{array}$ \\
\hline 3 & Fasilitas Sekolah & $\begin{array}{l}\text { Kondisi fasilitas sekolah sebagai penunjang pendidikan } \\
\text { baik secara kuantitas maupun kualitas belum memadai }\end{array}$ \\
\hline 4 & $\begin{array}{l}\text { Peran Serta Orang Tua } \\
\text { Siswa }\end{array}$ & $\begin{array}{l}\text { Orang tua siswa kurang berperan aktif terhadap } \\
\text { pendidikan putera-puteri mereka baik di lingkungan } \\
\text { sekolah maupun keluarga }\end{array}$ \\
\hline \multicolumn{3}{|r|}{ Opportunities (Peluang) } \\
\hline 1 & Minat Masyarakat & $\begin{array}{l}\text { Masyarakat masih berminat } \\
\text { pendidikan putera-puteri mereka }\end{array}$ \\
\hline 2 & $\begin{array}{l}\text { Efisiensi Anggaran } \\
\text { Pemerintah }\end{array}$ & $\begin{array}{l}\text { Biaya operasional sekolah bisa lebih ditekan } \\
\text { dibandingkan dengan sistem sekolah konvensional }\end{array}$ \\
\hline 3 & Kenakalan Remaja & $\begin{array}{l}\text { Aktifitas siswa bisa dimonitor dan diarahkan ke arah yang } \\
\text { positif sehingga kenakalan remaja bisa dikendalikan }\end{array}$ \\
\hline 4 & Mutu Pendidikan & $\begin{array}{l}\text { Mutu pendidikan bisa meningkat dengan peran serta yang } \\
\text { aktif baik dari pemerintah maupun masyarakat }\end{array}$ \\
\hline \multicolumn{3}{|r|}{ Threats (Ancaman) } \\
\hline 1 & Tuntutan Masyarakat & $\begin{array}{l}\text { Desakan dan harapan dari masyarakat untuk memperoleh } \\
\text { kualitas pendidikan yang lebih baik bagi putera-puteri } \\
\text { mereka cukup tinggi }\end{array}$ \\
\hline 2 & Manajemen Sekolah & $\begin{array}{l}\text { Manajemen sekolah menjadi lebih kompleks karena ada } \\
\text { dua tingkat pendidikan dalam satu sekolah dengan satu } \\
\text { kepala sekolah }\end{array}$ \\
\hline 3 & Pemahaman Masyarakat & $\begin{array}{l}\text { Masyarakat masih belum paham dengan kebijakan- } \\
\text { kebijakan yang dikeluarkan pemerintah daerah terkait } \\
\text { pendidikan }\end{array}$ \\
\hline 4 & Pelimpahan Wewenang & $\begin{array}{l}\text { Terjadinya tumpang tindih dan saling kontradiksi dalam } \\
\text { pelimpahan wewenang dari pemerintah pusat dan daerah }\end{array}$ \\
\hline
\end{tabular}

1.440. Dengan demikian, merumuskan kabupaten Purwakarta dapat didasarkan pada kebijakan Sekolah Satu Atap Terpadu di faktor-faktor yang memaksimalkan Strengths 
dan mengurangi Threats (strategi ST).

Faktor Strengths yang paling berpengaruh adalah siswa bisa melanjutkan pendidikan ke tingkat SMP dengan nilai 0.407. Temuan ini sejalan dengan hasil penelitian Sawirdi (2016) dimana Sekolah Satu Atap Terpadu ini bisa memberikan kemudahan akses pendidikan kepada siswa SD yang telah lulus untuk melanjutkan ke tingkat SMP. Kemudian Faktor Strength yang paling berpengaruh kedua adalah dukungan pemerintah daerah dengan nilai 0.402 . Hal ini dibuktikan dengan besarnya anggaran yang digelontorkan oleh pemerintah daerah kabupaten Purwakarta untuk pendidikan yaitu sekitar 33\% dari seluruh total anggaran (Pemerintah Kabupaten Purwakarta, 2019). Dukungan pemerintah daerah tidak hanya pada sisi anggaran tetapi juga pada konten kurikulum yang berupa pendidikan karakter berbasis kearifan lokal (Gunawan, et al., 2017), meskipun kurikulum ini sebagai Strength hanya memperoleh nilai sebesar 0.320 . Dengan anggaran pendidikan sebesar $33 \%$ dari total anggaran, seharusnya mampu meredam Threat yang berpotensi paling besar untuk timbul yaitu manajemen sekolah menjadi lebih kompleks dengan nilai 0.315. Salah satu kebijakan yang bisa dilakukan dalam

Gambar 1.

SWOT-Analytic Network Process (ANP) Sekolah Satu Atap Terpadu

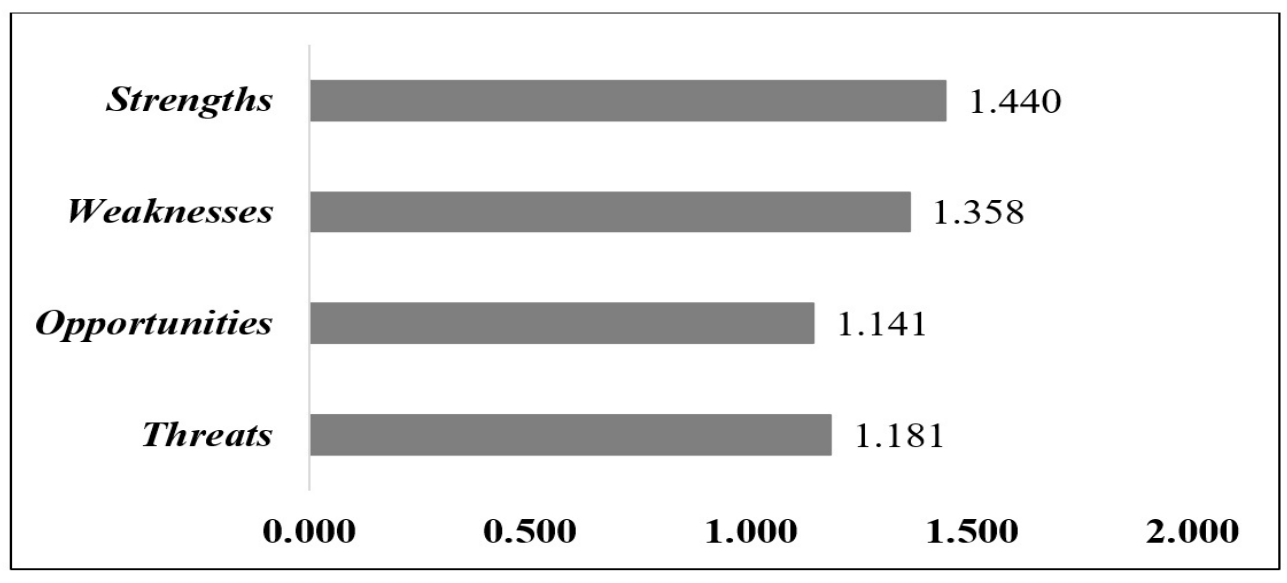

mengurangi Threatiniadalah denganmenambah dan meningkatkan kualitas SDM sekolah sehingga mampu menangani kompleksitas manajemen yang timbul. Meskipun Sekolah Satu Atap Terpadu bisa menciptakan efisiensi anggaran dari sisi operasional tetapi masih belum sepadan dengan potensi kompleksitas yang ditimbulkan. Hal ini dikarenakan dari analisis SWOT-ANP menunjukkan bahwa Opportunities untuk menciptakan efisiensi anggaran bernilai paling rendah yaitu hanya 0.206. Threat paling besar kedua adalah pelimpahan wewenang yang tidak jelas antara pemerintah pusat dan pemerintah daerah. Dari semua Threats yang ada justru Threat ini sulit ditangani oleh pemerintah daerah kabupaten
Purwakarta. Menurut Sugiharto (2013) Threat ini terjadi karena baik pemerintah pusat maupun pemerintah provinsi tidak memberikan kewenangan sepenuhnya kepada pemerintah kabupaten untuk melaksanakan kebijakannya sendiri, sehingga terjadi ketidak sesuaian implementasi kebijakan dengan keadaan yang sesungguhnya terjadi di lapangan.

\section{SIMPULAN DAN SARAN}

Sekolah Satu Atap Terpadu merupakan salah satu cara untuk bagi pemerintah untuk menyukseskan program wajib belajar 9 tahun khususnya di kabupaten Purwakarta. Akan tetapi dalam pelaksanaan di lapangan banyak 
dalam maupun dari luar. Melalui analisis SWOTAnalytic Network Process (ANP) penelitian ini menyimpulkan bahwa Sekolah Satu Atap Terpadu di kabupaten Purwakarta mempunyai nilai tertinggi pada Strengths antara lain siswa bisa melanjutkan sekolah sampai tingkat SMP dan dukungan pemerintah daerah baik dari sisi anggaran maupun dari sisi kurikulum, sehingga keputusan/kebijakan bisa diformulasikan dengan mengoptimalkan Strengths tersebut. Analisis SWOT-Analytic Network Process (ANP) juga menunjukkan Threats yang berpotensi muncul antara lain manajemen sekolah menjadi lebih kompleks dan pelimpahan wewenang yang tidak jelas antara pemerintah pusat dan pemerintah daerah. Kompleksitas manajemen yang timbul bisa ditangani apabila sekolah mempunyai jumlah SDM yang berkompeten dalam menanganinya. Sedangkan pelimpahan wewenang bisa yang tumpang-tindih bisa diurai jika ada komunikasi terbuka antara pemerintah pusat, provinsi, dan kabupaten. Selain itu, Sugiharto (2013) menambahkan

\section{REFERENSI}

Badan Pusat Statistik Kabupaten Purwakarta, 2018. Kabupaten Purwakarta dalam Angka 2018. Purwakarta: Badan Pusat Statistik Kabupaten Purwakarta.

Direktorat Jenderal Pendidikan Dasar dan Menengah, 2019. Data Pokok Pendidikan Dasar dan Menengah. [Online] Available at: http://dapo.dikdasmen.kemdikbud. go.id/sp/1/020000 [Accessed 25th June 2019].

Görener, A., 2012. Comparing AHP and ANP: An Application of Strategic Decisions Making in a Manufacturing Company. International Journal of Business and Social Science, 3(11), pp. 194-208.

Gunawan, G., Nugraha, Y., Sulastiana, M. \& Harding, D., 2017. Manajemen Pendidikan Karakter Berbasis Kearifan Lokal pada Sekolah Menengah Pertama
Negeri di Kabupaten Purwakarta. Humanitas, 1(3), pp. 147-160.

Kementerian Pendidikan \& Kebudayaan, 2019. Data Master - Satuan Pendidikan (NPSN). [Online] Available at: http://referensi. data.kemdikbud.go.id [Accessed 3rd July 2019].

Kharisma, B. \& Hadiyanto, F., 2018. Analysis of Potential Sectors and Policy Priorities of Regional Economic Development in Maluku Province. Etikonomi, 18(1).

Mahmud, S., 2015. Evaluasi Program SD-SMP Satu Atap di SMP Negeri 7 Liukang Tupabbiring Kabupaten Pangkep. Universitas Negeri Makassar.

Pemerintah Kabupaten Purwakarta, 2019. Laporan Kinerja Pertanggungjawaban Tahun Anggaran 2017-2018. Purwakarta: Pemerintah Kabupaten Purwakarta.

Saaty, T. L., 2008. Decision Making with the Analytic Hierarchy Process. International Journal Service Sciences, 1(1), pp. 83-98. Sawirdi, 2016. Implementasi Kebijakan SDSMP Negeri 4 Satu Atap di Desa Pongkar Kecamatan Tebing Kabupaten Karimun. Jurnal Pendidikan, 17(2), pp. 113-120.

Sugiharto, N., 2013. Kebijakan Pendidikan dan Implementasinya; Upaya Peningkatan Kualitas Sumber Daya Manusia di Kabupaten Purwakarta. Informasi, 18(02), pp. 225-250.

Yüksel, İ. \& Dağdeviren, M., 2007. Using the Analytic Network Process (ANP) in a SWOT Analysis - A Case Study for a Textile Firm. Information Sciences, 177(16), pp. 3364-3382. 